\title{
The Deconstruction of the Femininity of the Main Character in Andrea Hirata's Ayah Novel: Throwing the Shackles of Community Conventions
}

\section{Arini Vika Sari}

Pendidikan Bahasa dan Sastra Indonesia, Fakultas Bahasa dan Seni, Universitas Negeri Yogyakarta arinivika.2019@student.uny.ac.id

\begin{tabular}{ll}
\hline \hline Informasi artikel & \\
\hline Sejarah artikel: & \\
Diterima: & I Februari 202I \\
Revisi: & I4 September 202I \\
Dipublikasikan & 30 Oktober 202I \\
\hline
\end{tabular}
\begin{abstract}
ABSTRAK
Penelitian ini bertujuan untuk membongkar femininitas yang terdapat dalam novel Ayah karya Andrea Hirata dengan tokoh utama perempuan Marlena dan tokoh utama laki-laki Sabari. Penelitian ini merupakan penelitian deskripsi kualitatif dengan menggunakan metode analisis wacana kritis. Sumber data berupa novel Ayah karya Andrea Hirata terbitan Bentang 2017. Teknik pengumpulan data dengan baca dan catat dalam kartu data. Instrumen pengumpulan data adalah human instrument atau peneliti sendiri dengan menggunakan pendekatan feminisme postmodern. Dalam menganalisis data, dilakukan dengan tiga tahap, yakni (I) reduksi kata; (2) penyajian data; dan (3) penarikan kesimpulan. Hasil dekonstruksi femininitas menunjukkan bahwa terdapat enam wujud dekonstruksi femininitas dalam novel Ayah karya Andrea Hirata, yaitu: citra feminin, hasrat feminin, kecantikan, kebiasaan feminin, pekerjaan feminin, dan prinsip feminin. Femininitas dalam novel Ayah dimiliki dan dipraktikkan oleh tokoh utama perempuan dan tokoh utama laki-laki yang memiliki keunggulan dan kelemahan. Melalui dekonstruksi femininitas postmodern, Andrea Hirata mampu menampilkan tokoh utama sebagai subjek konstruksi femininitas yang mencoba memerdekakan diri dari belenggu konvensi masyarakat.
\end{abstract}

Kata kunci:

Dekonstruksi

Femininitas

Feminisme

Postmodern

Gender

\section{Key word: \\ Deconstruction \\ Femininity \\ Feminism \\ Postmodern \\ Gender}

\begin{abstract}
This study aims to uncover the femininity contained in the novel Ayah by Andrea Hirata with the female main character Marlena and the male main character Sabari. This research is a qualitative descriptive research using critical discourse analysis method. The data source is the novel Ayah by Andrea Hirata published in Bentang 20I7. The technique of collecting data is by reading and recording on a data card. The data collection instrument is the human instrument or the researcher himself using a postmodern feminism approach. In analyzing the data, it was carried out in three stages, namely (I) word reduction; (2) data presentation; and (3) drawing conclusions. The results of deconstruction of femininity show that there are six forms of deconstruction of femininity in Andrea Hirata's novel Ayah, namely: feminine image, feminine desire, beauty, feminine habits, feminine work, and feminine principles. Femininity in the novel Ayah is owned and practiced by the female main character and the male main character who have strengths and weaknesses. Through the deconstruction of postmodern femininity, Andrea Hirata is able to present the main character as the subject of the construction of femininity who tries to free himself from the shackles of society's conventions.
\end{abstract}

Copyright (C) 2018 Universitas Ahmad Dahlan. All Right Reserved

\section{Introduction}

Society has always tended to perceive that gender is nature. In fact, in essence nature is about gender physically. Gender itself is a marker of roles that are built biologically and sexually that can be formed through environmental construction and can be exchanged, so that gender can be influenced by cultural, economic, social, and environmental factors (Jamili \& Roshanzamir, 2017; Safitri \& Anggraini, 2020). Indonesia, the majority of which still believes in and practices a patriarchal culture, is confined to the stereotype of society that the male gender is masculine and the female gender is feminine. Patriarchal culture has placed women in the second position after men. As Allen's (2016:208) view states that women have been made second-class citizens as revealed from the history of feminism.

The view that is formed in patriarchal culture always states that men are more dominant over women and children in family life and social life (Francis, Archer, Moote, Witt, \& Yeomans, 2017; Safitri \& Anggraini, 2020). 
In fact, gender roles are mostly limited by social norms that define women as wives, mothers and are limited to the scope of household life, while men do not do much household work. That is why men are superior to women (Smith, Parrott, \& Tharp, 2015; Fox, et al., 2018; Jatnika \& Hermawan, 2018). With the general construction of society that develops regarding the general, it is difficult for groups that are outside the mainstream to be accepted in society.

Gender discourse is closely related to feminism which can shape the subject by constructing and opening up insights about the true definition of gender, the dichotomy between masculine and feminine, and gender relations inherent in socio-cultural (Zulkarnain \& Wiyatmi, 2018: I09-II0). So it is not surprising that feminists ranging from essential feminists to postmodern feminists also criticize gender discourse that has been ingrained in social life. Postmodern feminism tries to identify women's identities, language, and related writings that are able to deconstruct or subvert the superiority of male discourse (Jamili \& Roshanzamir, 2017:1 I6). Furthermore, postmodern feminism is able to show a different perspective by distorting ideas and ideas that have been considered negative, ugly, lacking, or non-existent (Indriani \& Wiyatmi, 2019).

In addition, femininity is also seen as the basis for understanding the forms of oppression that have been experienced by women (Hollows, 2010:I4). In fact, Derrida (I988:I2) states that every sign can certainly be separated from its basic context which can then be placed into a new context, so that the sign can have unlimited meaning. That is, femininity which also has a sign that can be deconstructed. Deconstruction is the term given when the critical process of reduced oppositions in one part or reduces some of the other oppositions in a process of textual meaning (Eagleton, 2005:I I4-I I5). In addition, deconstruction is also used to show an agenda or part that is not shown which contains many shortcomings and lameness behind the texts presented (Zulfadhli, 2012:I33). Deconstructing the text means being able to recognize these internal contradictions, to uncover traces of strangeness and displacement in what seems to be firmly embedded (Widyawati, 2020:170).

Novels are imaginative literature that by default it is purely fictitious. However, that does not mean that the narrative of events contained in the novel never occurs happen at all (Rahman \& Hidayat, 2018:35). Novels by Andrea Hirata generally depict feminist female characters who never give up and dare to be confined in a patriarchal society. In the novel Ayah, Andrea Hirata tries to describe the female character in Marlena's visualization that is different from the female characters in the novels he has made, such as the character of Bu Mus in the novel Laskar Pelangi in 2005, the character Maryamah in the novel Cinta di Dalam Gelas in 2010, and the character Enong in the novel Padang Bulan 2010. This study tries to understand the femininity of the main character in Andrea Hirata's Ayah novel by using a postmodern feminist paradigm.

Many studies have used Andrea Hirata's Ayah novel as the data source. The title of Stylistics in Andrea Hirata's Ayah Novel by Laili Fatmalinda, Wahyudi Siswanto and Endah Tri Priyatni in 2016 shows how the stylistics contained in the novel can be described through the characteristics of diction, sentence structure, and the use of figure of speech found in the novel Ayah. Based on the results of the analysis, it shows that there are peculiarities of diction, sentence structure, and figure of speech in Andrea Hirata's Ayah novel. In addition, a study was found with the title Analysis of the Structure of the Novel Ayah by Andrea Hirata by Palupi Wahyu in 2019 which aims to analyze the intrinsic elements as elements that build and how all the elements unite in a literary work. The results show that all the elements are interrelated and connected with a comprehensive meaning in the form of love and affection which is described patience and sincerely.

This researcher is different from previous research. The focus of this research is the deconstruction of femininity. This study aims to identify and explain the deconstruction of femininity in Andrea Hirata's Ayah novel, which is depicted with a female main character named Marlena and a male protagonist named Sabari. Marlena is a beautiful woman who has a stubborn nature, likes to travel, is independent, and does not hesitate to show her identity to the community. Meanwhile, Sabari is described as a loving, patient and accepting man. Wiyatmi (2020:4) reveals that literary studies that use a feminist perspective are studies based on feminist methods with the aim of digging up unrevealed and missing information regarding women's information, both specifically and in general, by identifying women's activities that are omitted and deleted.

Based on the description above, in this study the method used is a critical discourse analysis method with a postmodern feminism approach to express femininity contained in Andrea Hirata's Ayah novel with the female main character Marlena and the male main character Sabari. This research needs to be done because with the study of critical discourse analysis, we can understand women from a feminist perspective through the author's thoughts and interpretations from a male perspective. 


\section{Method}

This research is a qualitative descriptive research using critical discourse analysis paradigm. Critical discourse analysis is used to find out how men and women are narrated and presented in Andrea Hirata's Ayah novel. The representation between men and women can show the role of patriarchal ideology which has been subordinated to masculinity in constructing femininity. The data source used in this research is the novel Ayah by Andrea Hirata published in Bentang 2017. The research data is in the form of text in the form of words, phrases and sentences contained in the novel Ayah by Andrea Hirata published in Bentang 2017.

Data collection techniques by reading and recording in data cards. The data collection instrument is the human instrument or the researcher himself using postmodern feminism. Postmodern feminism approach is used by focusing on data and sharpening data analysis regarding the deconstruction of femininity, such as the deconstruction of femininity which not only shows a hierarchical reversal, but also reveals the phalogocentrism that occurs in gender discourse. The data analysis technique in this study uses semantic and pragmatic equivalents in analyzing the femininity of the main character in Andrea Hirata's Ayah novel. The data analysis stage in this study was carried out in three stages, namely (I) word reduction, carried out by recording data in the form of words, phrases and sentences that destructed the main character's femininity, identifying the data, and classifying it; (2) data presentation, carried out by presenting classification results and presenting representative data; (3) drawing conclusions by generalizing and looking for generalized data.

\section{Result and Discussion}

There are six forms of femininity deconstruction that have been found from the process of analyzing the femininity of the main character in Andrea Hirata's Ayah novel. The six deconstructions of femininity are: feminine image, feminine desire, beauty, feminine habits, feminine work, and feminine principles. These findings can be seen from the following discussion.

\section{Deconstruction of Feminine Image}

The appearance of the feminine image of the main character that appears in Andrea Hirata's Ayah novel is deconstructed in two ways. First, by presenting the main female character against the feminine image (shy) that exists in women. The main character Marlena who is usually called Lena is visualized as an Indonesian woman who is brave and not shy in her attitude and behavior. Marlena's attitude as the main female character shows that she is a free, independent woman and does not depend on anything. This can be seen from the following quote.

"Lena has no idea how much her letter affected Zuraida. He was amazed by Lena's stance, how her best friend had traveled and never hesitated to be herself, someone who dared to stand up straight to say what she wanted and didn't want, someone who could free herself from hanging on to anything, including the shame she felt. unreasonable" (Hirata, 2017:245).

The quote on the data shows that the character Marlena as the main character in the novel Ayah shows something that is very contrary to the construction of patriarchal society. The attitude of the main female character described by Andrea Hirata will certainly be considered strange and outside the conventions of society. The quote above can also emphasize that women are not involved in the construction of femininity. Women are only the object of the construction of femininity in the life of a patriarchal society. This can be seen in Marlena's friend Zuraida, who has been confined by conventional rules and norms in a patriarchal society.

The second deconstruction of feminine image is by visualizing the main male character who has a feminine image. In Andrea Hirata's novel Ayah, the depiction of the male main character emerges from the character Sabari. The character of Sabari is described as the main male character who has a feminine image that is shy, passive, passionate and gentle. Andrea Hirata tries to destruct male characters who are shy with everything that educates human nature, even though these traits are very contrary to the construction of masculinity and femininity in the conventions of patriarchal society.

"A notebook for you, Lena," said Sabari as gently as possible, embarrassed and nervous. The book was a prize for hope for three student poetry writing competitions, Sabari's highest achievement. He wanted Lena to be proud of him. You don't have to, says Lena” (Hirata, 2017:3).

The quote is very clearly described by Andrea Hirata how he teaches human nature between the male and female main characters. Although in the quote the two main characters are very contrary to the conventions that 
apply in society, especially the patriarchal Indonesian society, Andrea Hirata tries to emphasize that the events in the scene have happened in real life.

\section{Deconstruction of Feminine Desire}

The feminine desire contained in Andrea Hirata's Ayah novel is deconstructed by showing the image of the main female character Marlena who openly opposes feminine desires. Andrea Hirata describes Marlena's character as very easy to file for divorce. Marlena's character considers herself beautiful and able to captivate any man she admires. But in the end, the marriage ended in a religious court. This can be proven in the following quote.

"The trial didn't last long. Sabari's heart seemed to be cut when he saw the court clerk cut his marriage book and Lena's marriage book. His Majesty tapped the hammer. The assembly closed the session" (Hirata, 2017:212).

It doesn't stop there, the femininity of the main character shown by Marlena is also seen when she doesn't feel sad or suffer from divorce at all. Not long ago, the main female character, Marlena, was ready to remarry with another man, only a matter of days apart. This desire is very contrary to the desire of women in general who only want to marry once in a lifetime with a man who loves her. This can be proven from the following quote.

"What he knows is that it has only been three days since the court's decision, it has been reported that Lena is close to a Vespa motorcycle dealer. Buncai said, "They want to get married, Marlena and Zorro will be brought to Pangkal Pinang” (Hirata, 2017:219).

In the male main character, Andrea Hirata deconstructs feminine desires by showing male characters who have feminine desires. In the novel Ayah, it is explained that if Sabari as the main character has a daughter, then he will name his child with the name Kemasi. It was considered by Sabari as a form of harmony if he gave the name to his daughter. Take a look at the following data excerpts.

"If it's a girl, Sabari will definitely go by one name: Kemasi. He wants his son to be diligent in packing up" (Hirata, 2017:179).

The data quote above is certainly related to stereotypes based on gender. Women in the convention of patriarchal society are only allowed to carry out domestic activities related to domestic work. So that the community convention that has been going on for a long time then forms the nature of women who tend to be weak due to always being associated with women's domestic work such as diligently tidying and cleaning the house every time.

\section{Deconstruction of Beauty}

Andrea Hirata as a male writer is able to define beauty in the novel Ayah through various perspectives. The description of beauty in the novel $A y a h$, is first visualized by naming a female character whose name alone is capable of making men unable to forget her. Note the following quote.

“... Lena is not only his love, but also his fate. The beautiful-eyed Kelumbi woman was sent down from the sky for him. That's the law of his life, de jure, de facto" (Hirata, 2017:76).

The quote above shows that the name Lena, which is used as the nickname of the female main character, Marlena, has harmony and compatibility with the attractive female self-image. The name was made by Andrea Hirata as a beauty identity for women, so as to be able to balance the description of the main character with the name of the character in the character.

Not only by name, Andrea Hirata also defines beauty with a woman's physical self-image that is able to make leleki hypnotized when she sees it because she has extraordinary charm. As the view of Fahs (2015:3) which states that a woman who has an ideal thin or plump body with a white skin color is considered an ideal body image in society. So that the main female character, Marlena, becomes a subject that captivates the hearts of men because her beauty has an ideal physical image. This can be seen from the quote below.

"Many times they rubbed their eyes and convinced themselves that the man with the unkempt face was Sabari, and the sweet girl with beautiful gems, with deep dimples like a well in the old police station was Marlena" (Hirata, 2017:172). 
Furthermore, Andrea Hirata also visualizes the main female character Marlena as a smart woman. With the advantages possessed by the main character, the deconstruction of beauty in the novel Ayah by Andrea Hirata makes the main character worthy of breaking the conventions of patriarchal society. Take a look at the following data excerpts.

"Lena is confident and a fast learner, can also use a computer, her English is decent. Wherever he applies for a job, as long as there is an interview and people can see his appearance, he will definitely be accepted" (Hirata, 2017:244).

In addition to displaying the construction of beauty, Andrea Hirata also deconstructs beauty by using her beauty as a tool to dominate men.

"He was talking to himself that there was something in the woman in the photo. A person who sets many conditions is a sign of a responsible person. One quality that suits him. A week later Manikam started to write letters with the woman in Toboali" (Hirata, 2017:217).

The beauty reconstructed by Andrea Hirata in the character of Marlena who has a very beautiful face, is able to make men crazy about her. In addition to the data above, there is also data that narrates how Marlena with her beauty was able to lure an established widower who is not easy to rekindle romance and willing to accept Marlena as a wife with all her past stories actually afraid of losing and being abandoned by Marlena. In fact, according to Paechter (2018:122) view, it is stated that in the construction of culture in terms of sexual relations, masculine is more physically dominant in relation to femininity. This is certainly the opposite of the main character Marlena. Pay attention to the following data.

"Manikam tried to persuade Lena not to go, but Lena is not someone to be easily conquered. Manikam struggled to get permission from the office for their second divorce" (Hirata, 2017:243).

Besides Manikam, another male character who is described as falling in love with Marlena is Jon. The excitement of his former life immediately changed when he met Marlena. It can be seen from the following data excerpt.

"From a person who is tired, muted, and stuffy, after getting to know Lena, Jon suddenly becomes cheerful" (Hirata, 2017:253).

However, the beauty possessed by Marlena makes it very easy to take actions and decisions. She is very easy to say goodbye to a man who loves her very much and even frustrates the man she left behind. This can be proven from the following quote.

"John has repeatedly persuaded Lena and asked for forgiveness like the Lebaran people, but Lena is an iron woman with a stand that is more upright than the flagpole in an independent field" (Hirata, 2017:266).

\section{Deconstruction of Feminine Habits}

Andrea Hirata's deconstruction of feminine habits is carried out in two ways. The first way is to show the main female character who does not want to do activities that are usually done and carried out by women. Hamilton et al. (2019:316) views that women who embody femininity can be done by taking advantage of their social. As the main character Marlena described by Andrea Hirata as a woman who rarely stays at home. This habit has not changed even though he is married and has a child. In fact, Marlena also always raises her voice in front of her father. He did not want to do women's work in general. She never cooks, does not serve her husband Sabari and does not want to take care of her children. The habit of the main female character Marlena is certainly very contrary to the habits of women in general. This can be seen in the following quote.

"In a short time, Sabari immediately memorized Lena's actions, for example what time she left the house, what time she came home, what day she didn't come home, and which men took her home. Sabari also knew that only a short time after Lena got home, a heated argument would erupt between her and her father. Their 
screams were heard as far as the factory and neighboring houses. At first Sabari was surprised, but since this happens all the time, he gets used to it." (Hirata, 2017:150).

In a patriarchal society, women must have the habit of getting up early to do domestic work such as cooking and preparing breakfast and can only be active in the house. Meanwhile, men are the backbone of the family. In contrast to Marlena who does not care about the norms and rules in a patriarchal society. In fact, the negative stigma that labels it is ignored. He is actually proud of his activities that are considered to be able to satisfy his desires alone. The habit of Marlena's character is a form of resistance to the construction of femininity in the life of a patriarchal society. This can be seen in the following quote.

"It's trivial, Lena likes music, the guy can't tell the difference between dangdut music and reggae music. Lena loves to travel, she wants to see the world, the man loves to see his turtledoves. Lena doesn't want to spend the rest of her life with a man who wants to stay at home." (Hirata, 2017:234).

The second way that Andrea Hirata's work shows is by showing a male main character who has feminine habits and traits. The main character Sabari in Andrea Hirata's novel Ayah is narrated as a man who is not ashamed to cry because he is sad. This is certainly very contrary to the principles and characteristics of masculinity, namely not crying and not whining. In a patriarchal society, a man who shows his crying is considered a man who is not masculine because for a patriarchal society crying is a habit carried out by women. However, in Andrea Hirata's novel Ayah, the character Sabari shows his tears in public. Andrea Hirata seems to want to show that crying is something human, not masculine or feminine, as in the following quote.

"It was raining heavily. Patience does not take shelter. He continued to lead his bicycle while crying bitterly" (Hirata, 2017:230).

\section{Deconstruction of Feminine Job}

Feminine work is always synonymous with the role of a woman such as taking care of the house, cooking, and taking care of children and husband. In the novel Ayah, by Andrea Hirata, the main character, Marlena, does not want to do the feminine work. This can be seen from the following quote.

"Unfortunately Lena's feelings are different from Sabari's. He soon returned to his old hobby. At first he went away for a while, then went away for a long time, then stayed overnight, then didn't come home. Her soul is too rebelious, full of rebellion, to be attached to a husband and children. For him, there is nothing more terrible in this world than being trapped in an unhappy marriage” (Hirata, 2017:18I-I82).

\section{Deconstruction of the Feminine}

Principle Andrea Hirata deconstructs the feminine principle by showing the main male character who has feminine principles. The main character named Sabari is described as a character who is patient, compassionate, generous and polite.

"Bogel is annoyed because Sabari never provoked. He pulled Sabari's collar and challenged him to a fight. Sabari does not fight back, only smiles, because he will not lower himself by using his mouth to use and will not humiliate himself by using his hands to hit" (Hirata, 2017:80).

The quote above describes how Sabari as a male character is very patient like the name given to the main character. In addition, the character of Sabari is described as a character who is able to replace the role of a mother, who loves and loves her son, Zorro, even though he knows that Zorro is not his biological child.

"How Sabari loves Zorro. Wanted her to hug him all the time. He was mesmerized by the beautiful little creature and all the goodness that radiated from it. He kissed the child from head to toes. At night, Sabari has trouble sleeping because he imagines various plans that will be passed with his son when he grows up" (Hirata, 2017:183).

Sabari also has another feminine trait. Andrea Hirata makes the main character Sabari as feminine. He has a very high demeanor. This can be seen from the following quote data. 
"Who told you to take it?! Who?! I can take it myself!" in fact, Sabari handed it over no less solemnly than the way the Regency Paskibraka handed over the flag” (Hirata, 2017:3).

Besides being polite, Sabari is also very calm. He is able to position himself according to his mood. Note the following quote.

"Suddenly, Sabari isn't the Sabari he used to be. He's calmer, takes more baths, and doesn't want to wear clothes stained with forest fruit sap" (Hirata, 2017:3I).

Not only that, Sabari's feminine nature is also shown when he meets Marlena. However, the opposite is true for Marlena. The following quote shows the feminine nature of Sabari.

"Five meters or so away from Lena, a polite distance she carefully maintains. They looked at each other at a glance, everything seemed to be in slow motion, but Lena seemed to be looking at the wind. Be patient like you're not there" (Hirata, 2017:67).

The last feminine trait and attitude in Sabari's character is melancholy. He is very sensitive and easily gets carried away by emotions. Of course this is not in the character of Marlena, who is strong and decisive. Note the following quote.

"Sabari saw as if one bicycle fell and then hundreds of other bicycles fell. In Lena's eyes. He felt pain. Lena broke her heart, Leboy's nudity broke her" (Hirata, 2017:69).

\section{Conclusion}

Deconstruction of femininity from the novel Ayah by Andrea Hirata shows that there are six forms of femininity, namely: feminine image, feminine desire, beauty, feminine habits, feminine work, and feminine principles. The results of the deconstruction of femininity show that femininity is not only owned and practiced by female characters. The female main character and the male main character both practice femininity which in the view of society, the two characters, namely Marlena and Sabari, seem to exchange roles in married life. Thus, the concept of femininity is open to various new meanings that have advantages and disadvantages. Through the deconstruction of postmodern femininity, Andrea Hirata is able to show female characters as subjects who give a clearer and clearer picture of femininity. Femininity is not always bad and negative for women. There is a wisdom of self-independence that Andrea Hirata tries to describe from the two main characters of the novel Ayah.

\section{Acknowledgement}

This research was designed and compiled with the support and encouragement from various parties. The authors would like to thank the Yogyakarta State University, the lecturers and friends and family who have provided support. The author also does not forget to thank the editorial team of the Indonesian Language and Literature Education Bahastra, Ahmad Dahlan University, who has provided space and opportunity in publishing this article. Hopefully this article can contribute to learning, especially in critical literacy activities.

\section{REFERENCES}

Allen, K. R. (2016). Feminist theory in family studies: History, reflection, and critique. Journal of Family Theory and Review, 8(2), 207-224. https://doi.org/IO.IIII/jftr.I2I33.

Bunkle, P. (2016). The I944 education act and second wave feminism. Women's History Review, 25(5), 79I-8II. https://doi.org/I0.1080/096I2025.2015.I132877.

Derrida, J.(1988). Limited inc: Jacques Derrida. Diterjemahkan oleh Samuel Weber. Evanstone: Northwestern University Press.

Eagleton, T. (2005). Literary theory: An introduction 2nd Ed. Oxford: Blackwell Publishing.

Fahs, B. (2015). The dreaded body : Disgust and the production of " appropriate" femininity femininity. Jounal of Gender Studies, 9236(December), I-I4. https://doi.org/I0.I080/09589236.2015.1095081

Fox, L., et al. (2018). The Lives of Rural Women and Girls. Washington: Bill \& Melinda Gates

Foundation. https://www.odi.org/sites/odi.org.uk/files/resource-documents/I2466.pdf.

Francis, B., Archer, L., Moote, J., Witt, J. de, \& Yeomans, L. (2017). Femininity, science, and the denigration of the girly girl. British Journal of Sociology of Education, 38(8), I097-I I 10. 
https://doi.org/IO.I080/0I425692.20I6.I253455.

Hamilton, L. T., Armstrong, E. A., Seeley, J. L., \& Armstrong, E. M. (2019). Hegemonic femininities and intersectional domination. Sociological Theory, 37(4), 3I5-34I. https://doi.org/I0.I I77/0735275I I9888248

Indriani, L., \& Wiyatmi. (2019). Femininitas dalam pandangan novelis laki-laki: Analisis kritik sastra feminis terhadap novel dawuk: kisah kelabu dari rumbuk randu karya Mahfud Ikhwan. PROSIDING SEMINAR LITERASI IV

"Menjawab Tantangan Pendidikan Melalui Literasi Budaya Pada Era Distups", I69-I76. Semarang: I4 November 2019.

Jamili, L. B., \& Roshanzamir, Z. (2017). Postmodern feminism: Cultural trauma in construction of female identities in Virginia woolfs the waves. Advances in Language and Literary Studies, 8(4), I I4. https://doi.org/I0.7575/aiac.alls.v.8n.4p.II4

Jatnika, A. W., \& Hermawan, F. F. (2018). Menjadi lelaki sejati : Maskulinitas dalam komik daring webtoon Indonesia. MUDRA, 33(I), 60-66.

Paechter, C. (2018). Rethinking the possibilities for hegemonic femininity: Exploring a Gramscian framework. Women's Studies International Forum, 68(August 2017), I2I-I28.

Rahman, F., \& Hidayat, R. (2018). Kearifan lokal dan benturan budaya orang Indonesia di negara luar dalam novel edensor karya Andrea Hirata. BAHASTRA, XXXVIII(I), 34-42. https://doi.org/http://dx.doi.org/I0.26555/bahastra.

Safitri, V. N., \& Anggraini, P. (2020). Feminis construction on Balinese culture in kalamata novel by Ni Made Purnama Sari. Kementerian Pendidikan Dan Kebudayaan, 2I(I), 44-6I. https://doi.org/I0.24036/komposisi.v2IiI.I02795.

Smith, R. M., Parrott, D. J., \& Tharp, A. T. (20I5). Deconstructing hegemonic masculinity: The roles of antifemininity, subordination to women, and sexual dominance in men's perpetration of sexual aggression. Psychology of Men and Masculinity, I6(2), I60-I69. https://doi.org/I0.I037/a0035956

Widyawati, M. (2020). Dekonstruksi dominasi laki-laki terhadap perempuan rural dalam novel aib dan nasib karya Minanto. Seminar Nasional Bahasa Dan Sastra Indonesia Unpam, 3 Oktober 2020, 212-218.

Wiyatmi. (2020). Perempuan dalam kesusastraan Indonesia. Seminar Nasional Bahasa Dan Sastra Indonesia Unpam, 2I2218.

Zulfadhli, Z. (2012). Dekonstruksi dalam cerpen malin kundang, ibunya durhaka karya A.A. Navis. Komposisi: Jurnal Pendidikan Bahasa, Sastra, Dan Seni, IO(2). https://doi.org/I0.24036/komposisi.vI0i2.62

Zulkarnain, J. A., \& Wiyatmi. (2018). Dekonstruksi Femininitas dalam Novel-novel Karya Eka Kurniawan: Dari Pekerjaan Sampai Kecantikan. Poetika, 6(2), I09. https://doi.org/I0.22I46/poetika.v6i2.40I88. 